\title{
Up-Regulation of Cytoskeletal Proteins in Activated Microglia
}

\author{
E.M. Abd-El-Basset J. Prashanth K.V.V. Ananth Lakshmi \\ Department of Anatomy, Faculty of Medicine, Kuwait University, Kuwait
}

\section{Key Words}

Cytokines - Microglia - Actin - Tubulin - Tumor necrosis factor- $\alpha \cdot$ Interleukin- $1 \beta$

\begin{abstract}
Objectives: This study investigates how the tumor necrosis factor (TNF- $\alpha$ ) and interleukin-1 $\beta$ (IL-1 $\beta$ ) affect the morphology, organization, and expression of actin, $\beta$ actin and tubulin in microglia. Materials and Methods: Microglia cultures were prepared from neopallia of newborn mice. Immunofluorescence, immunoblotting, and ELISA studies were used. Results: When microglia are treated with TNF- $\alpha$, IL-1 $\beta$ or a combination of both for 1-5 days, the majority change from an ameboid to a large, round and flat shape. F-actin and $\beta$-actin isoform, which are diffusely arranged throughout the cytoplasm before stimulation, are reorganized into filamentous bundles underneath and parallel to the cell membrane, which projects into many ruffles. This organization is maintained even after withdrawal of the cytokines. The dense microtubule network of tubulin in nontreated microglia becomes less dense and extends to occupy the cytoplasm of the treated microglia. Immunoblotting shows that the amount of total actin, $\beta$-actin isoform and tubulin increases in treated microglia. In addition, IL-1 $\beta$ and a combination of both TNF- $\alpha$ and IL-1 $\beta$ stimulate the re-
\end{abstract}

\section{KARGER}

Fax +41613061234

E-Mail karger@karger.ch

www.karger.com
(C) 2004 S. Karger AG, Basel

1011-7571/04/0136-0325\$21.00/0

Accessible online at:

www. karger.com/mpp lease of IL- 6 by microglia. Conclusion: This study suggests that TNF- $\alpha$ and IL- $1 \beta$ have an effect on the expression of cytoskeletal proteins similar to some extent to that of LPS. The up-regulation of actin, $\beta$-actin and tubulin may play a key role in the motility and recruitment of microglia to the area of central nervous system inflammation.

Copyright @ 2004 S. Karger AG, Basel

\section{Introduction}

Cells resident within the central nervous system (CNS) can synthesize, secrete, and respond to inflammatory cytokines, not only contributing to the responses to injury or immunological challenge within the CNS but also regulating their own growth and differentiation. Microglia might contribute to the early phase of cytokine production, whereas astrocytes might contribute to the late phase of the reaction [1-4].

Interleukin-1 $\beta$ (IL-1 $\beta$ ) is a very potent molecule acting both at the periphery as well as within the CNS. It is produced by a variety of cell types including glia and neurons. IL-1 $\beta$ may have an important role in the developing brain as maintenance and growth-promoting factor [5]. In normal adult brain the level of cytokines, IL-1 $\beta$ and tumor necrosis factor alpha (TNF- $\alpha)$ are generally very low, but
Dr. Ebtesam M. Abd-El-Basset, MD, PhD, Ass. Prof.

Department of Anatomy, Faculty of Medicine, Kuwait University

PO Box 24923

13100 Safat (Kuwait)

Tel. +965 531 2300, ext. 6275, Fax +965 531 8454, E-Mail ebtesam@hsc.kuniv.edu.kw 
can increase dramatically in response to injury, trauma, or any interference with normal homeostasis [6].

Bacterial wall lipopolysaccharide (LPS), a potent inflammatory agent, stimulates microglia to secrete a number of cytokines in cultures including IL-1, IL-8, and TNF- $\alpha$ [7-13] and causes them to become large, flat and round [14]. These changes in cell morphology and cell activity are accompanied by changes in the cell motility, organization of cytoskeletal proteins, modulation of the cell membrane and up-regulation of actin [15-17]. Actin plays an important role in the maintenance of cell structure and cell motility. The isoform $\beta$-actin, which has been shown to be developmentally regulated in rat brain [18], is restricted to the somatodendritic domains of neurons in adults, and is also detected in microglia more than in neurons and astrocytes. Immunoreactivity is particularly high in ameboid microglia after exposure of the brain to kainate injury [19].

The signals promoting the morphological changes that adapt microglia to specific functions are still unknown. It is also not known whether the elevated levels of cytokines IL- $1 \beta$ and TNF- $\alpha$ have a similar effect on the morphology, cytoskeletal organization and relative amount of cytoskeletal proteins. Thus, the effect of IL- $1 \beta$ and TNF- $\alpha$ on microglia need to be assessed alone without LPS.

Previous studies have shown that some chemokines act as motility-stimulating factors that induce migration and changes in the actin organization in microglia [20]. This study investigates how IL- $1 \beta$ and TNF- $\alpha$ affect the morphology, organization, and expression of tubulin, actin, and $\beta$-actin in microglia growing in tissue culture. In addition, their effect on the expression of IL-6 is estimated to test the functional activity of the treated microglia.

\section{Materials and Methods}

\section{Microglia Cultures}

Neopallial cultures were prepared from newborn Balb/c mice as described previously $[17,21]$. The neopallia were dissected out and then gently forced through a sterile $75-\mu \mathrm{m}$ Nitex mesh. The cells were suspended in modified Eagle's minimum essential medium containing $5 \%$ horse serum. Aliquots of $5 \times 10^{6}$ nigrosine-excluding cells were plated in $75-\mathrm{cm}^{2} \mathrm{Nunc}$ culture flasks and incubated at $37^{\circ} \mathrm{C}$ in a humidified atmosphere of $5 \% \mathrm{CO}_{2}$ in air for 10 days with medium changed every 2-3 days. At that stage the cells form a dense monolayer of GFAP-positive astroglia. The cultures were then subjected to nutritional deprivation, i.e. growing without medium change for an additional 12-16 days, to generate microglia that grew in medium progressively conditioned by astroglia (A-CM). The microglia were then treated with $0.25 \%$ trypsin for $15 \mathrm{~min}$, and $3 \times 10^{4} / \mathrm{cm}^{2}$ microglia were plated on glass coverslips $(11 \times 22 \mathrm{~mm})$ for immunofluorescence study. Microglia in flasks or on coverslips were treated with either $200 \mathrm{U} / \mathrm{ml}$ of mouse recombinant IL-1 $\beta, 200 \mathrm{U} / \mathrm{ml}$ of mouse recombinant TNF- $\alpha$ or a combination of both IL- $1 \beta$ and TNF- $\alpha$ for 1-5 days in A-CM. For ELISA experiments the microglia were treated for 2, 4, 8, 16, 24, 48, and $96 \mathrm{~h}$. In the control, the cells were left in A-CM for the same period without treatment. For withdrawal effects some cultures were treated with cytokines for 2 days, then washed several times in Puck's solution and incubated for another 3 days in A-CM without the cytokines.

\section{Immunofluorescence}

Cells grown on glass coverslips were fixed for 10 min with $3.7 \%$ formaldehyde in phosphate-buffered saline (PBS), then washed 3 times in PBS. The fixed cells were extracted for 2 min with $-20^{\circ} \mathrm{C}$ methanol. The cells were then treated with either mouse monoclonal antibody to $\beta$-actin isoform or to $\beta$-tubulin (Sigma) diluted 1:100 in PBS for $1 \mathrm{~h}$, followed by fluorescein-conjugated $\mathrm{F}(\mathrm{ab})_{2}$ fragment of donkey antimouse IgG (Jackson Immuno-Research), diluted 1:100 in PBS, for $45 \mathrm{~min}$. To visualize the distribution of F-actin (formed by all the actin isoforms), the cells were fixed in $3.7 \%$ formaldehyde and extracted with $0.1 \%$ TX-100 Triton, then labeled with rhodamine phalloidin, which binds to F-actin (molecular probe) diluted $1: 20$ in PBS for 45 min. For controls, primary antibodies were omitted. All the staining was carried out at room temperature. The preparations were mounted in 50\% glycerol in PBS, $\mathrm{pH} 7.8$, and were examined with an Olympus photomicroscope equipped with a mercury vapor lamp, epifluorescence optics and appropriate interference filter.

\section{Polyacrylamide Gel Electrophoresis (PAGE)}

Microglia treated with IL-1 $\beta$, TNF- $\alpha$ or a combination of both for 1-2 days along with control were washed 3 times in PBS, scraped off the culture flasks with a rubber policeman and collected in PBS. The cells were immediately sonicated and the protein concentration was determined according to the method of Bradford [22]. The sonicated cells were dissolved in sodium dodecyl sulfate (SDS)-containing sample buffer and boiled for $3 \mathrm{~min}$. The same amount of proteins from each sample $(20 \mu \mathrm{g} /$ well) was analyzed electrophoretically in $10 \%$ SDS-PAGE according to the method of Laemmli [23].

\section{Immunoblotting}

The proteins in the gel were transferred to nitrocellulose sheets by a modification of the method of Towbin et al. [24]. After transfer, the nitrocellulose sheets were incubated for $1 \mathrm{~h}$ with $3 \%$ bovine serum albumin in PBS. The nitrocellulose sheets were then incubated overnight at room temperature with either mouse monoclonal antibody to actin (reacts with all actin isoforms), to $\beta$-actin, or to $\beta$-tubulin diluted 1:500 in PBS containing 3\% bovine serum albumin. The sheets were then incubated for $4 \mathrm{~h}$ with affinity-purified goat antimouse IgG conjugated to horseradish peroxidase diluted 1:1,000 in PBS containing $3 \%$ bovine serum albumin. The color was developed using freshly prepared $0.05 \%$ 4-chlor-1-naphthol and $0.015 \% \mathrm{H}_{2} \mathrm{O}_{2}$ in PBS. All the chemicals for PAGE and immunoblotting were purchased from Bio-Rad Lab. Ltd.

Immunoblots of five independent experiments were scanned using the snapescan 1212 scanner and Adobe PhotoShop 5.0 program. The relative levels of actin, $\beta$-actin and tubulin expression were determined by analyzing the pixel intensity of the bands using an imaging analysis program (Image $\mathrm{J}$, version $1.04 \mathrm{~b}$, Wayne Rasband, NIH). The percentage of the protein expression was calculated in the following manner. The average background protein levels in 
Fig. 1. Phase-contrast image of microglia culture isolated from dense mouse neopallia. The microglia have an ameboid shape with many short processes, which expand at their ends to form lamellipodia. Bar $=50 \mu \mathrm{m}$.

Fig. 2. Phase-contrast image of microglia treated with $200 \mathrm{U} / \mathrm{ml}$ IL-1 $\beta$ for 1 day, showing that the majority of the microglia acquire large, round and flat shape (arrows). Bar = $50 \mu \mathrm{m}$.
1

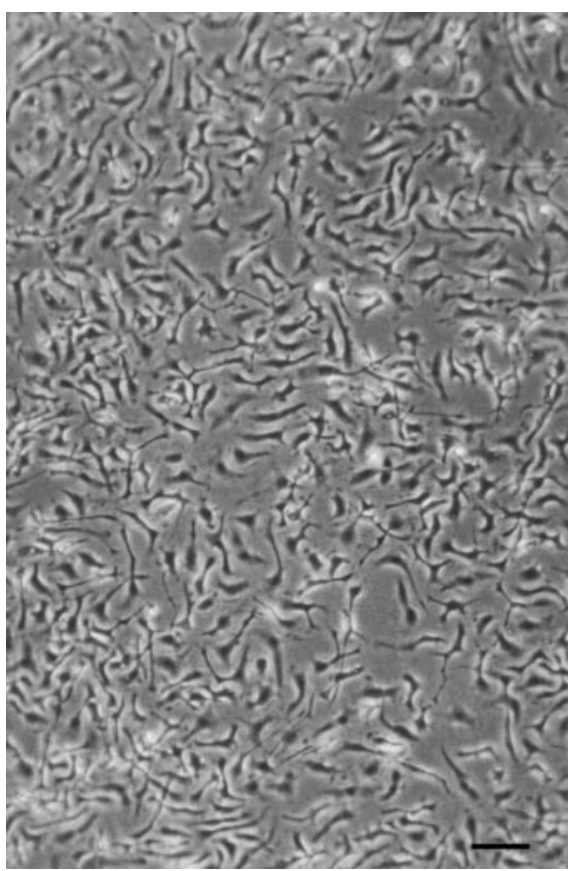

2

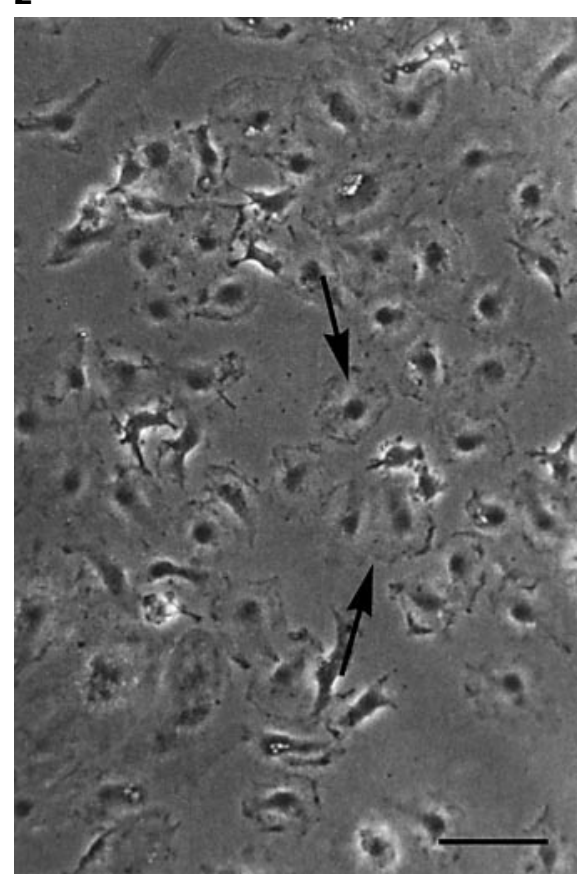

the lane, excluding the bands, were first subtracted from both the control and treatment bands. The percentage of the increase in intensity (I) of cytokine-treated cells (T) compared to the control (C) was calculated as follows:

$\%$ of increase in the intensity $=100 \times \frac{\text { mean I of T }- \text { mean I of C }}{\text { mean I of C }}$

Mouse IL-6 ELISA Assay

The mouse IL-6 ELISA kit (Biosource International Inc.) was used for the quantitative determination of mouse IL-6 in microglia culture media collected from nontreated microglia (control) and microglia treated with IL- $1 \beta$, TNF- $\alpha$ or a combination of both for 2 , $4,8,16,24,48$, or $96 \mathrm{~h}$ as described by the protocol of the kit. The experiments were repeated 3 times. The calculations of mean concentration, standard deviation and percentage coefficient of variation were done with Genesis Software version 2.20. The quantity of mouse IL-6 present in examined samples was expressed in picograms per milliliter.

\section{Results}

\section{Morphology of Microglia}

Microglia Growing in Cultures. The isolated microglia expressed CR3 receptors, which bind Mac-1 antibody. Approximately $90 \%$ of microglia were ameboid cells with many short thick processes that expand at their ends to form lamellipodia. The rest of the microglia in cultures were small and round in shape (fig. 1).
Effect of Cytokines. After microglia were treated with IL- $1 \beta$, TNF- $\alpha$, or a combination of both for 1 day the majority of the cells assumed a large, round and flat shape (fig. 2, 3). The treated microglia retained the round shape throughout the remainder of the experiment (5 days). The ameboid microglia with processes, which did not transform into round cells, became larger and extended lamellipodia in different directions (fig. 3). After withdrawal of each cytokine for 3 days, most of the microglia reassumed elongated appearance (fig. 4).

\section{Immunofluorescence}

Organization of F-Actin and $\beta$-Actin Isoform in Microglia. Microglia express $\beta$-actin isoform. Both of F-actin and $\beta$-actin networks had the same distribution in nontreated microglia. They appeared granular and diffuse, rather than filamentous in the cytoplasm of the cell body as well as in the processes of the ameboid microglia (fig. 5). Stress fibers were not present in microglia.

Effect of Cytokines on the Organization of F-Actin and $\beta$-Actin in Microglia. When microglia were treated with IL-1 $\beta$ for 1 day, most of the F-actin and $\beta$-actin isoform became reorganized by forming filamentous bundles underneath the cell membrane ruffles. The reorganization of both F-actin and $\beta$-actin was observed in both large, round, flat cells and ameboid cells with processes (fig. 6, 7). Microglia treated with TNF- $\alpha$ or a combination 
3

Fig. 3. Phase-contrast image of microglia treated with $200 \mathrm{U} / \mathrm{ml}$ TNF- $\alpha$ for 5 days, showing that the majority of the microglia acquire large, round and flat shape (arrows). The ameboid microglia with processes, which did not transform into round cells, became larger and extended lamellipodia in different directions (arrowheads). Bar $=$ $50 \mu \mathrm{m}$.

Fig. 4. Phase-contrast image of microglia treated with $200 \mathrm{U} / \mathrm{ml}$ IL-1 $\beta$ for 2 days, then washed and grown for another 3 days in A$\mathrm{CM}$, showing that the majority of the microglia become elongated in shape (arrows). Bar $=50 \mu \mathrm{m}$.

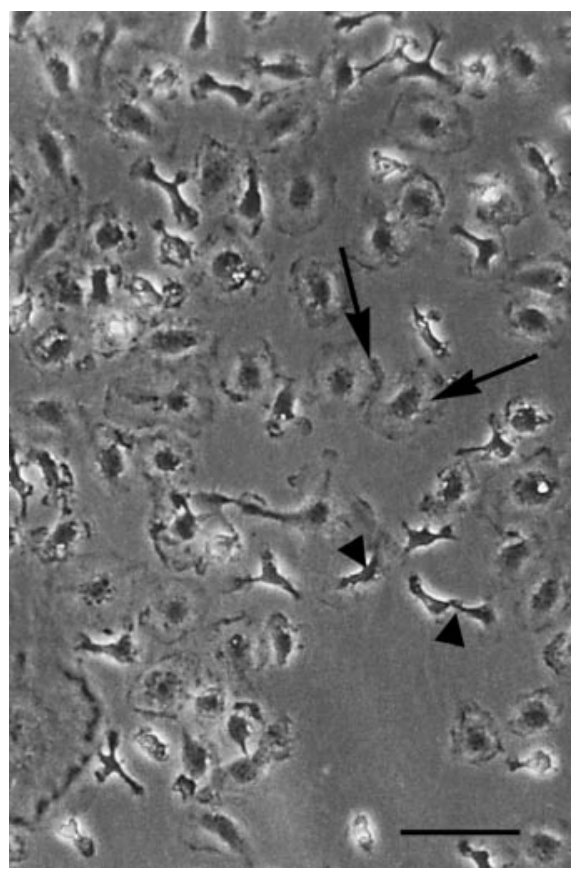

4

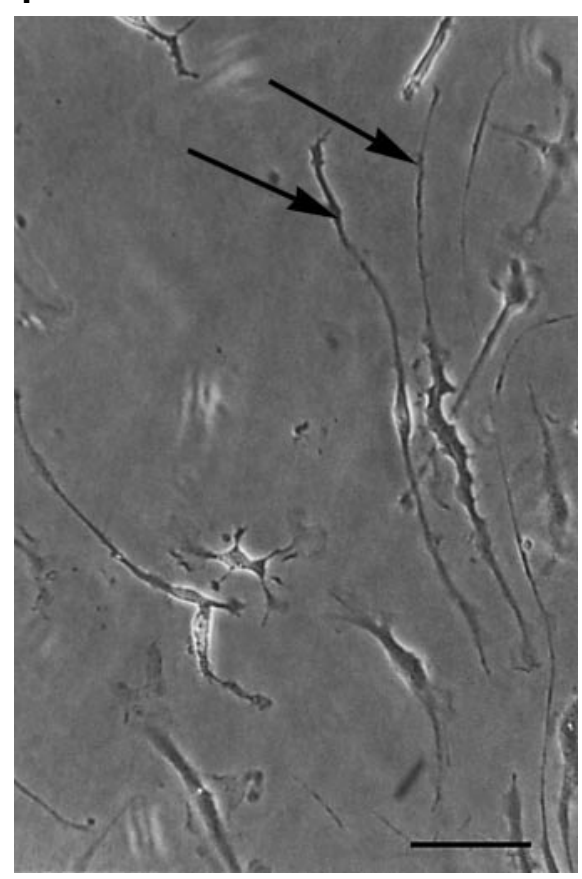

of both IL- $1 \beta$ and TNF- $\alpha$ for 1 day showed similar reorganization of $\mathrm{F}$-actin and $\beta$-actin as in microglia treated with IL-1 $\beta$ (not shown). The reorganization of both Factin and $\beta$-actin was seen up to 5 days in treated microglia and up to 3 days after withdrawal of the cytokines (fig. 8).

Organization of Tubulin in Microglia. The microtubule (MT) network in microglia growing in A-CM was arranged in the form of a dense network arising from one side of the nucleus and extended into the cytoplasm (fig. 9).

Effect of Cytokines on the Organization of Tubulin in Microglia. When the microglia were treated with IL-1 $\beta$ for 1-5 days, the MT network became less dense and extended to occupy all the cytoplasm of the large round cells (fig. 10). TNF- $\alpha$ or a combination of both IL-1 $\beta$ and TNF$\alpha$ had a similar effect on the organization of the MT network (not shown); however, after withdrawal of the cytokines for 3 days, the MT network became dense again.

\section{Immunoblotting}

We examined the changes in relative amounts of $\beta$ tubulin, total actin and $\beta$-actin isoform in untreated and cytokine-treated whole microglia homogenates. The expression of $\beta$-tubulin, total actin and $\beta$-actin isoform was up-regulated in microglia treated with IL-1 $\beta$, TNF- $\alpha$ (fig. 11, table 1) or a combination of both (not shown).

\section{IL-6 ELISA Assay}

IL-1 $\beta$ stimulated microglia to secrete IL-6. The secretion reached its highest level at $16 \mathrm{~h}$ of treatment, then it declined to almost the control level after 4 days of treatment. TNF- $\alpha$ had no effect on the secretion of IL- 6 by microglia, whereas treatment of microglia with a combination of both IL- $1 \beta$ and TNF- $\alpha$ stimulated microglia to secrete IL-6. The secretion of IL-6 also reached its highest level at $16 \mathrm{~h}$ of treatment and then suddenly decreased (fig. 12).

\section{Discussion}

Treatment of microglia with cytokines IL-1 $\beta$ and TNF$\alpha$ or a combination of both for 1 day caused dramatic morphological changes and reorganization of F-actin and $\beta$-actin isoform. The reorganization of the F-actin network into filamentous bundles underneath the membrane is similar to that induced by LPS and is responsible for the appearance of many membrane folds and small blebs [16, 17]. These observations support the suggestion that Factin and $\beta$-actin isoform could play a determinant role in the morphological changes of microglia [19]. Further treatment of microglia with cytokines for 5 days does not induce any further changes either in the morphology or organization of F-actin and $\beta$-actin. However, the treat- 
Fig. 5-7. Immunofluorescence images of control microglia growing in A-CM (5) and microglia treated with $200 \mathrm{U} / \mathrm{ml} \mathrm{IL}-1 \beta$ for 1 day $(\mathbf{6}, \mathbf{7})$ labeled with rhodamine phalloidin, which binds to F-actin $(\mathbf{5}, \mathbf{6})$ and antibody to $\beta$-actin (5, inset, $\mathbf{7})$. The ameboid microglia in control culture show fine networks of F-actin (5) and $\beta$-actin (5, inset), which appear as granules (arrows) rather than filaments. In treated microglia both F-actin (6) and $\beta$-actin (7) appear as thick bundles underneath the membrane ruffles. Bar $=20 \mu \mathrm{m}$.

Fig. 8. Immunofluorescence images of microglia treated with $200 \mathrm{U} / \mathrm{ml}$ IL-1 $\beta$ for 2 days, then washed and grown for another 3 days in A-CM and labeled by antibody to $\beta$-actin. $\beta$-Actin appears as thick bundles underneath the membrane ruffles. Bar = $20 \mu \mathrm{m}$.
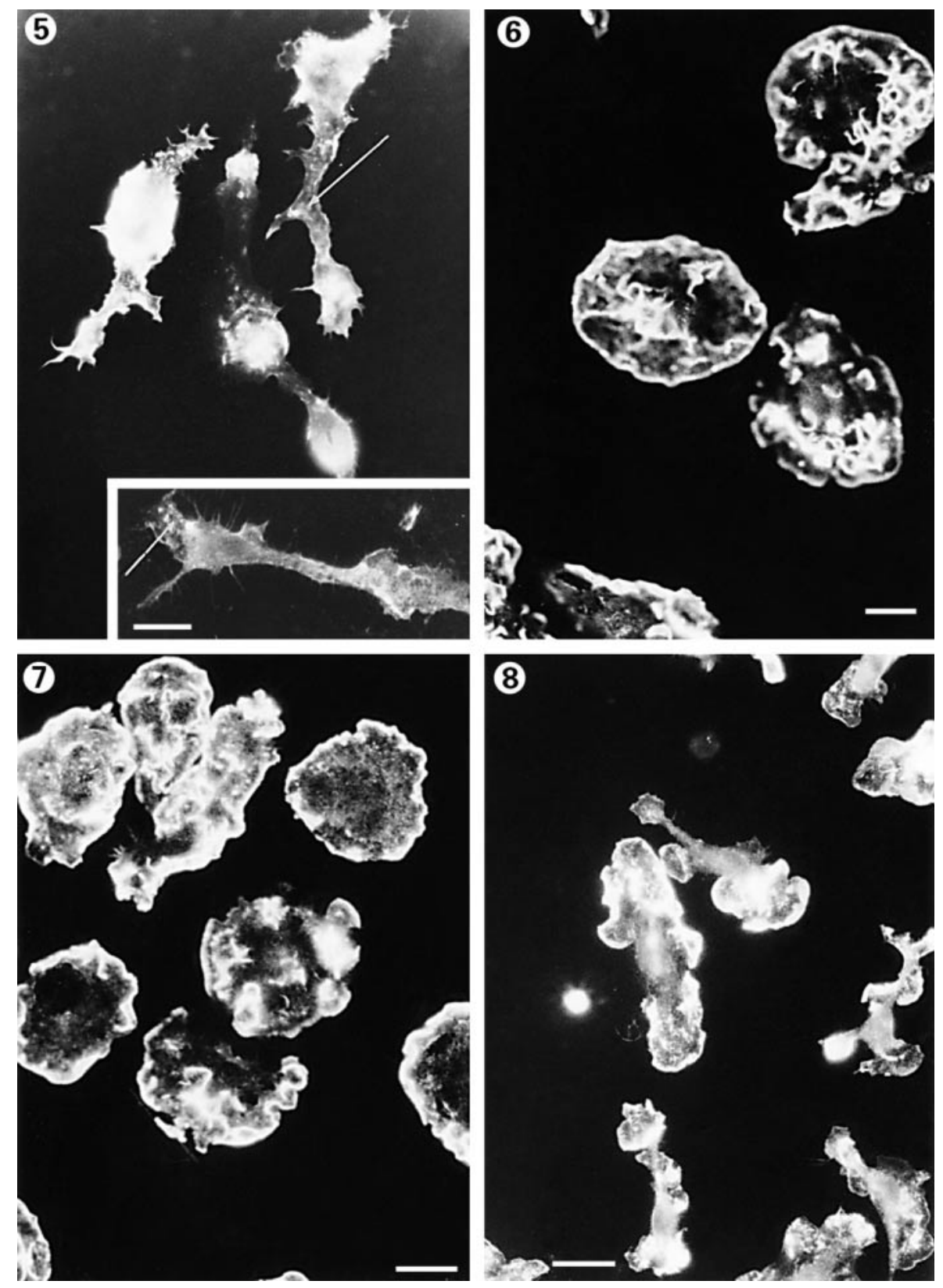

Table 1. $\%$ increase of actin, $\beta$-actin and $\beta$-tubulin after treatment with IL- $1 \beta$ and TNF- $\alpha$ for 1 and 2 days. Increase of intensity was calculated form 5 independent experiments. The level of each molecule was significantly increased by IL- $2 \beta$ and TNF- $\alpha$.

\begin{tabular}{|c|c|c|c|c|c|c|}
\hline \multirow[t]{2}{*}{ Treatment } & \multicolumn{2}{|c|}{ Actin, $\%$} & \multicolumn{2}{|c|}{$\beta$-actin, $\%$} & \multicolumn{2}{|c|}{$\beta$-tubulin, $\%$} \\
\hline & 1 day & 2 days & 1 day & 2 days & 1 day & 2 days \\
\hline IL-1 $\beta$ & $50 \pm 4$ & $52 \pm 5$ & $126 \pm 3$ & $117 \pm 4$ & $28 \pm 2$ & $32 \pm 3$ \\
\hline TNF- $\alpha$ & $62 \pm 3$ & $123 \pm 4$ & $154 \pm 6$ & $250 \pm 6$ & $120 \pm 2$ & $201 \pm 6$ \\
\hline
\end{tabular}


Fig. 9, 10. Immunofluorescence images of control microglia (9) and microglia treated with $200 \mathrm{U} / \mathrm{ml} \mathrm{IL-1} \beta$ for 5 days (10) labeled with antibody to $\beta$-tubulin showing that MT network in control microglia was arranged in the form of a dense network (9). MT network becomes less dense and extends to occupy all the cytoplasm of treated microglia (10, arrow). Bar $=10 \mu \mathrm{m}$.
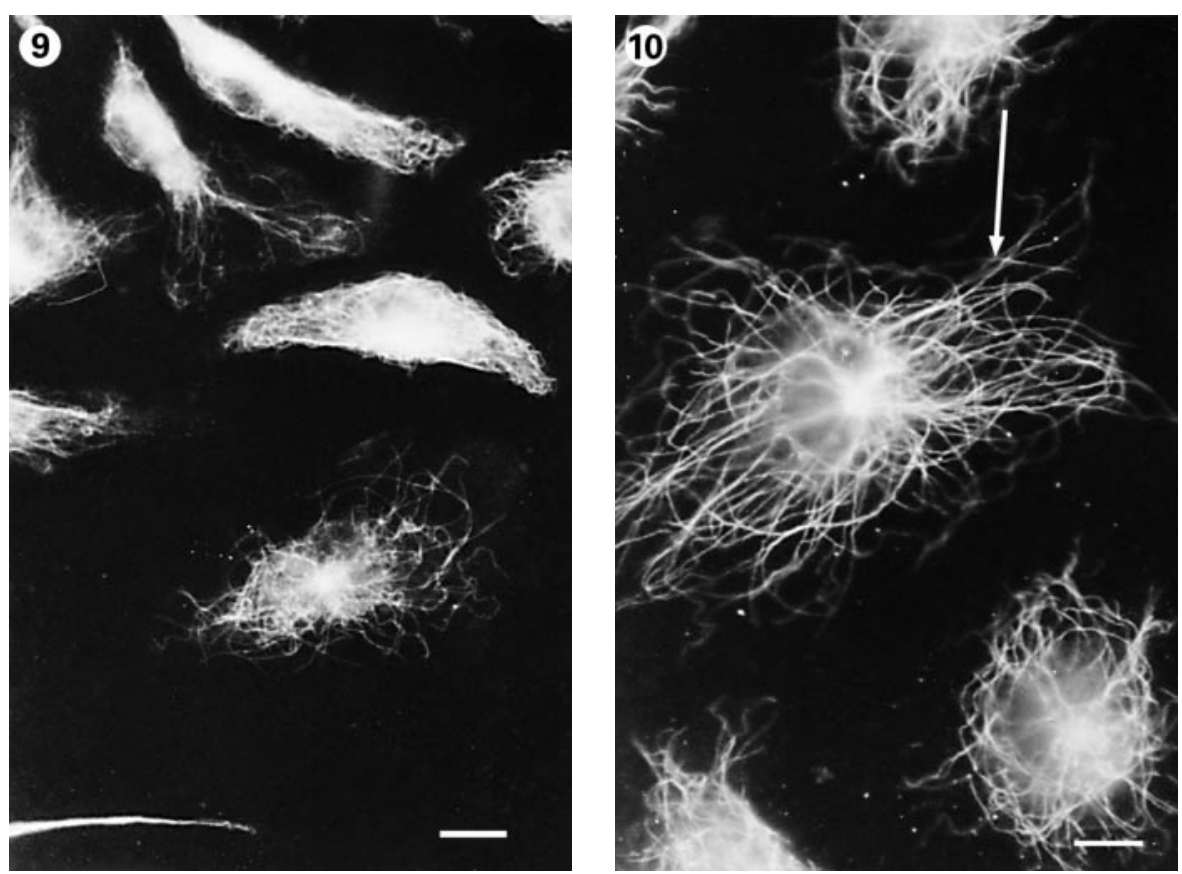

Fig. 11. IL- $1 \beta$ and TNF- $\alpha$ increase the expression of actin, $\beta$-actin, and $\beta$-tubulin by microglia. Protein extracts from 1-day (lanes 1, 5, 9) and 2-day (lanes 3, 7, 11) control cells, and 1-day (lanes 2, 6, 10) and 2-day (lanes $4,8,12$ ) treated microglia were resolved by $10 \%$ SDS-PAGE, transferred to nitrocellulose and immunolabeled by antibodies to total actin (lanes $1-4$ ), to $\beta$-actin isoform (lanes 5-8) and to $\beta$-tubulin (lanes 9-12).

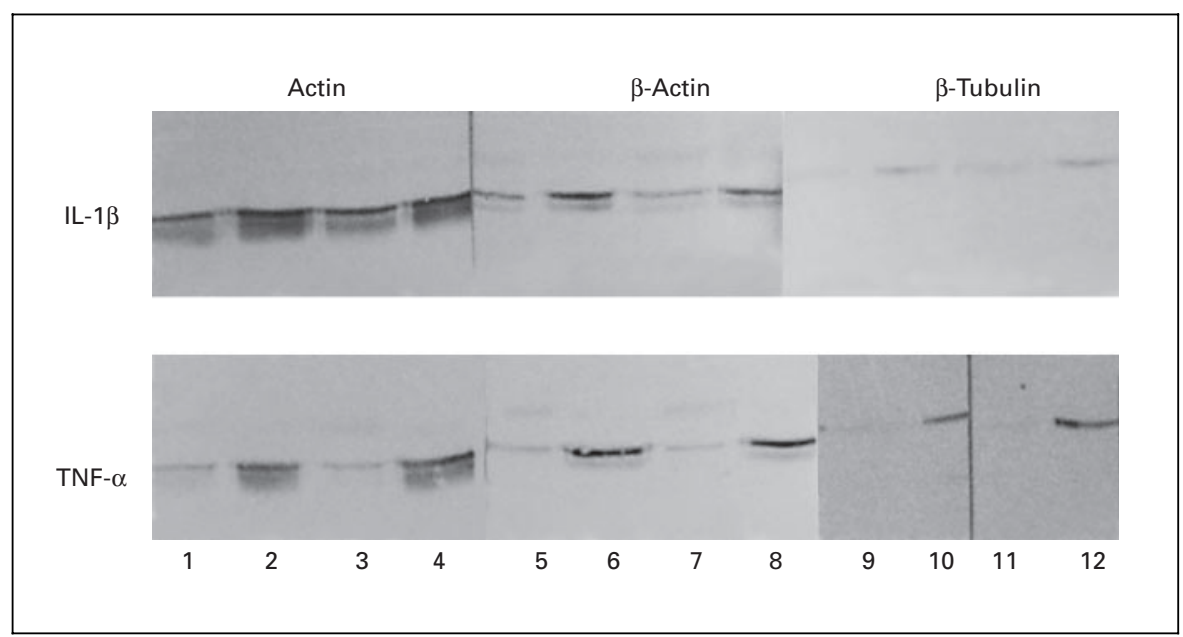

ment of the microglia with LPS for 5 days leads to the formation of large round cells with many microspike-like projections and reorganization of F-actin into thick bundles in these projections [16]. Microglia treated with cytokines and LPS do not show major changes in the organization of tubulin, the dense MT network becomes less dense and extends to occupy the large round cells. In addition, cytokines increase the expression of the cytoskeletal proteins, actin (all isoforms), $\beta$-actin isoform and tubulin.
Many studies demonstrated that in response to LPS, macrophages activate genes responsible for cytokine synthesis. Cytokine gene expression and protein secretion, which include IL-8, IL-1 $\beta$, TNF- $\alpha$, and GM-CSF, are time- and dose-dependent [25]. LPS stimulates microglia to produce many trophic factors including CSF-1 [26], IL1 [9, 27], IL-8 [12] and neurotrophins [10, 11]. These support the notion that activated microglia, which appear in damaged CNS, exert beneficial effects in post-traumatic CNS and enhance neurotic outgrowth [28]. Many effects 
Fig. 12. The effects of IL- $1 \beta$ and TNF- $\alpha$ on the secretion of IL-6 by microglia were estimated using ELISA method in control and microglia treated with $200 \mathrm{U} / \mathrm{ml} \mathrm{IL}-1 \beta$ or $200 \mathrm{U} / \mathrm{ml} \mathrm{TNF}-\alpha$ or a combination of both IL-1 $\beta$ and TNF- $\alpha$ for $1,2,4,8,16,24,48$, or 96 h. Bars are standard deviations from independent experiments.

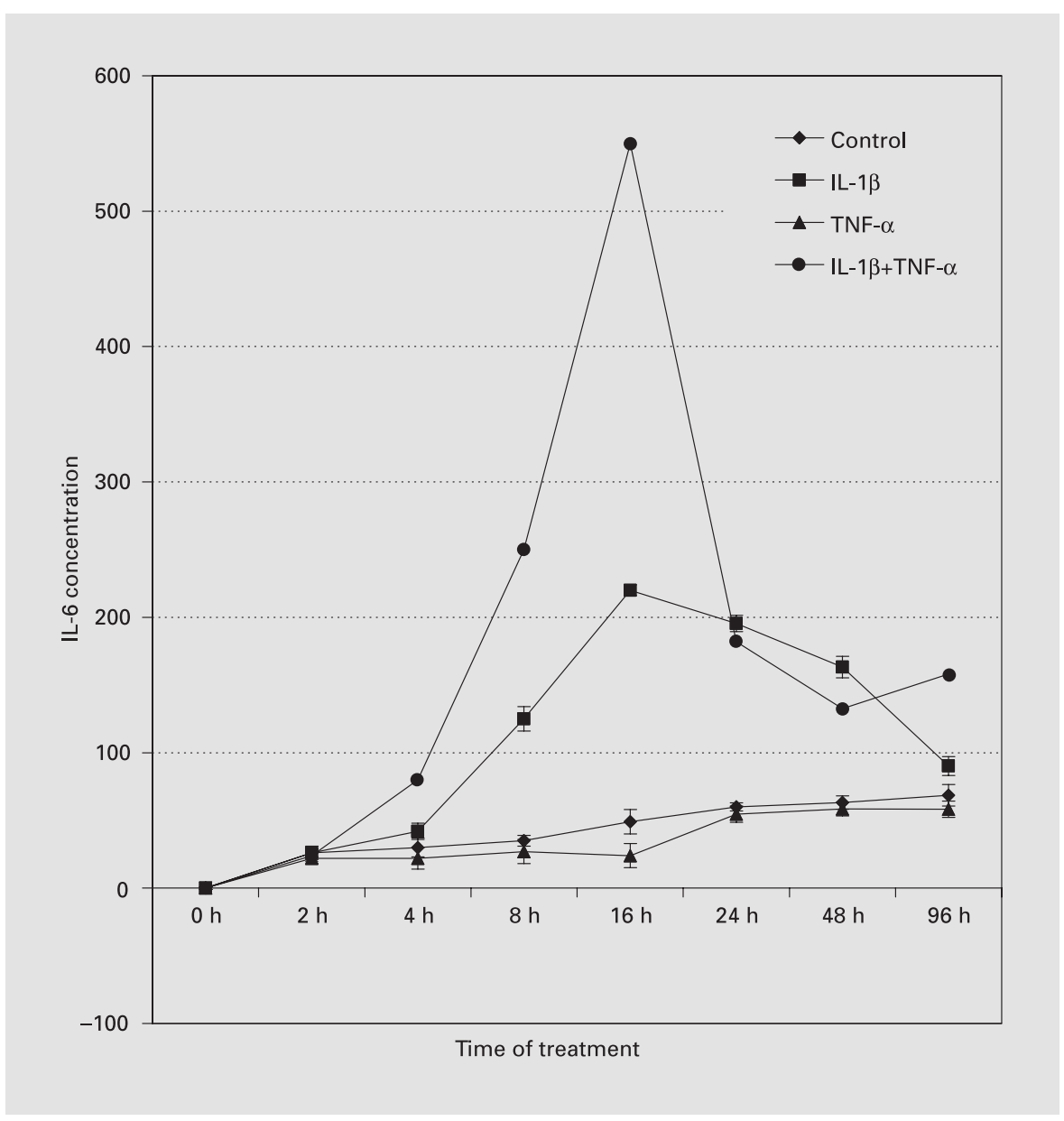

of endotoxin on animal cells are secondary to the overproduction of cytokines [29]. LPS also induces reorganization of microfilaments in macrophages [30] and dramatically increases the expression of actin-binding protein MARCKS [31]. LPS also induces morphological changes in microglia and reorganization of different components of the cytoskeleton, which reflect cell motility $[16,32]$ and increases the phagocytic activity of microglia [33]. It has been suggested that the changes in macrophage and microglia function are the results of a highly coordinated series of intracellular responses. Using protein tyrosine kinase inhibitors it was demonstrated that protein tyrosine kinases are involved in the signaling events of the LPS-induced productions of IL- $1 \alpha$, IL- 6 and TNF- $\alpha$ in microglia or astrocytes [34].

It has previously been shown that cytokines, gamma interferon and TNF- $\alpha$ induce morphological changes and collapse of actin filaments and cleavage of gelsolin in vascular smooth muscle cells [35]. In addition, IL-1 $\beta$, IL-1 $\alpha$ and TNF- $\alpha$ induce cytoskeletal reorganization in human umbilical vein endothelial cells [36]. The reorganization of cytoskeletal proteins indicates that cytokines affect the dynamic morphological changes in these cells. Current study suggests that TNF- $\alpha$ and IL- $1 \beta$ have an effect on the expression of cytoskeletal proteins in microglia similar to some extent to the effect of LPS when used for a short period (1-2 days). The up-regulation of actin, $\beta$-actin and tubulin may play a key role in the motility and recruitment of microglia to the area of CNS inflammation.

Microglia respond to and secrete cytokines. In response to IL-1 $\beta$ and a combination of both IL- $1 \beta$ and TNF- $\alpha$ microglia secrete IL-6; however, TNF- $\alpha$ alone does not stimulate microglia to secrete IL-6. Previous studies also showed that TNF- $\alpha$ induces IL- 6 activity in astrocytes and not microglia [37, 38]. IL-6 exerts neurotrophic, neuroprotective effects and can also function as a mediator of inflammation, demyelination and astrogliosis. In normal brain IL-6 level remains low; however, ele- 
vated expression occurs in injury, infection, stroke and inflammation. Cytokines have multiple and very complex effects on monocytes and macrophages. It is apparent that their effect on astroglia and microglia in the CNS is at least equally complex. It is important to understand the multiple effects of the cytokines on neural cells in order to devise effective therapy for the treatment of CNS trauma.

\section{Conclusion}

This study suggests that TNF- $\alpha$ and IL- $1 \beta$ have an effect on the expression of cytoskeletal proteins similar to some extent to that of LPS. The up-regulation of actin, $\beta$-actin and tubulin may play a key role in the motility and recruitment of microglia to the area of CNS inflammation.

\section{Acknowledgments}

This work was supported by Kuwait University through grant No. MA037.

\section{References}

1 Dickson DW, Lee SC, Mattiace LA, Yen SC, Brosnan C: Microglia and cytokines in neurological disease, with special references to AIDS and Alzheimer's disease. Glia 1993;7:75-83.

2 McGear PL, Kawamata T, Walker D, G Akiyama H, Tooyama I, McGeer E: Microglia in degenerative neurological disease. Glia 1993;7: 84-92.

3 Streit WJ: The role of microglia in brain injury. Neurotoxicology 1996;17:671-678.

$4 \mathrm{Yu}$ AC, Lau LT: Expression of interleukin-1 alpha, tumor necrosis factor alpha and interleukin-6 genes in astrocytes under ischemic injury. Neurochem Int 2000;36:369-377.

5 Araujo DM, Cotman CW: Differential effects of interleukin- $1 \beta$ and interleukin- 2 on glia and hippocampal neurons in culture. Int $\mathrm{J}$ Devl Neurosci 1995;13:201-212.

6 Rothwell NJ: Annual review prize lecture cytokines: Killers in the brain? J Physiol 1999;514 3-17.

7 Gebicke-Haerter PJ, Bauer J, Schobert A, Northoff $\mathrm{H}$ : Lipopolysaccharide-free conditions in primary astrocyte cultures allow growth and isolation of microglial cells. J Neurosci 1989;1:183-194.

8 Woodroofe MN, Sarna GS, Wadhwa M, Hayes GM, Loughlin AJ, Tinker A, Cuzner ML: Detection of IL-1 and IL-6 in adult rat brain, following mechanical injury, by in vivo microdialysis: Evidence of a role for microglia in cytokine production. J Neuroimmunol 1991;33: 227-236.

9 Van Dam AM, Brouns M, Louisse S, Berkenbosch F: Appearance of interleukin-1 in macrophages and in ramified microglia in the brain of endotoxin-treated rats: A pathway for the induction of non-specific symptoms of sickness? Brain Res 1992;588:291-296.

10 Heese K, Fiebich BL, Bauer J, Otten U: NF-кB modulates lipopolysaccharide-induced microglial nerve growth factor expression. Glia 1998; 22:401-407.
11 Miwa T, Furukawa S, Nakajima K, Furukawa Y: Lipopolysaccharide enhances synthesis of brain-derived neurotrophic factor in cultured rat microglia. J Neurosci Res 1997;50:10231029.

12 Ehrlich LC, Hu S, Sheng WS, Sutton RL, Rockswold GL, Peterson PK, Chao CC: Cytokine regulation of human microglial cell IL-8 production. J Immunol 1998;160:1944-1948.

13 Cai Z, Pan ZL, Pang YI, Evans OW, Rhodes PG: Cytokine induction in fetal rat brain and brain injury in neonatal rats after maternal lipopolysaccharide administration. Pediatr Res 2000;47:64-72.

14 Suzumura A, Marunouchi T, Yamamoto H: Morphological transformation of microglia in vitro. Brain Res 1991;545:301-306.

15 Bader MF, Taupenot L, Ulrich G, Aunis D, Ciesielski-Treska J: Bacterial endotoxin induces $(\mathrm{Ca} 2+)$ I transients and changes the organization of actin in microglia. Glia 1994;11: 336-344.

16 Abd-El-Basset EM, Fedoroff S: Effect of bacterial wall lipopolysaccharide on morphology, motility, and cytoskeletal organization of microglia in cultures. J Neurosci Res 1995;41: 222-237.

17 Abd-El-Basset EM: Bacterial endotoxin induces changes in the organization and expression of actin and modulation of the cell membrane of microglia. Med Principles Pract 2000; 9:81-90.

18 Weinberger R, Schevzov G, Jeffery P, Gordon K, Hill M, Gunning P: The molecular composition of neuronal microfilaments is spatially and temporally regulated. J Neurosci 1996;16:238252.

19 Plantier M, Der Terrossian E, Represa A: $\beta$ Actin immunoreactivity in rat microglia cells: Developmental pattern and participation in microglial reaction after kainate injury. Neurosci Lett 1998;247:49-52.
20 Cross AK, Woodroofe MN: Chemokines induce migration and changes in actin polymerization in adult rat brain microglia and a human fetal microglial cell line in vitro. J Neurosci Res 1999;55:17-23.

21 Hao C, Richardson A, Fedoroff S: Macrophage-like cells originate from neuroepithelium in culture: Characterization and properties of the macrophage-like cells. Int J Dev Neurosci 1991;9:1-14.

22 Bradford MM: A rapid and sensitive method for quantification of microgram quantities of protein utilizing the principles of protein dye binding. Anal Biochem 1976;72:248-254.

23 Laemmli UK: Cleavage of structural proteins during the assembly of the head of bacteriophage T4. Nature 1970;227:680-685.

24 Towbin H, Staehelin T, Gordon T: Electrophoretic transfer of proteins from polyacrylamide gels to nitrocellulose sheets: Procedure and some applications. Proc Natl Acad Sci USA 1979; 76:4350-4354.

25 Zhong WW, Burke PA, Hand T, Walsh MJ, Hughes LA, Forse RA: Regulation of cytokine mRNA expression in lipopolysaccharide-stimulated human macrophages. Arch Surg 1993; 128:158-164

26 Fedoroff S, Hao C, Ahmed I, Guilbert LJ: Paracrine and autocrine signalling in regulation of microglia survival; in Fedoroff, S, Juurlink BHJ, Doucette R (eds): Biology and Pathology of Astrocyte-Neuron Interactions. New York, Plenum Press, 1993, pp 247-262.

27 van Dam A-M, Poole S, Schultzberg M, Zavala F, Tilders FJ: Effects of peripheral administration of LPS on the expression of immunoreactive interleukin-1 $\alpha, \beta$, and receptor antagonist in rat brain. Ann N Y Acad Sci 1998;840:128138.

28 Rabchevsky AG, Streit WJ: Grafting of cultured microglial cells into the lesioned spinal cord of adult rats enhances neurites outgrowth. J Neurosci Res 1997;47:34-48.

29 Morrison DC, Ryan JL: Endotoxins and disease mechanisms. Annu Rev Med 1987;38: 417-432. 
30 Shinji H, Kaiho S, Nakano T, Yoshida T: Reorganization of microfilaments in macrophages after LPS stimulation. Exp Cell Res1991;193: 127-133.

31 Aderem A: The role of myristoylated protein kinase $\mathrm{C}$ substrates in intracellular signaling pathways in macrophages. Curr Top Microbiol Immunol 1992;181:189-207.

32 Ciesielski-Treska J, Ulrich G, Aunis D: Protein kinase $\mathrm{C}$-induced redistribution of the cytoskeleton and phosphorylation of vimentin in cultured brain macrophages. J Neurosci Res 1991;29:362-378.
33 Abd-El-Basset EM, Fedoroff S: Dynamics of actin filaments in microglia during $\mathrm{Fc}$ receptormediated phagocytosis. Acta Neuropathol (Berl) 1994;88:527-537.

34 Kong LY, Lai C, Wilson BC, Simpson JN, Hong JS: Protein tyrosine kinase inhibitors decrease lipopolysaccharide-induced proinflammatory cytokine production in mixed glia, microglia-enriched or astrocytes-enriched cultures. Neurochem Int 1997;30:491-497.

35 Geng YJ, Azumz T, Tang JX, Hatwig JH, Muszynski M, Wu Q, Libby P, Kwiatkowski DJ: Caspase-3-induced gelsolin fragmentation contributes to actin cytoskeletal collapse, nucleolysis, and apoptosis of vascular smooth muscle cells exposed to proinflammatory cytokines. Eur J Cell Biol 1998;77:294-302.
36 Molony L, Armstrong L: Cytoskeletal reorganizations in human vein endothelial cells as a result of cytokine exposure. Exp Cell Res 1991; 196:40-48.

37 Sawada M, Suzumura A, Marunouchi T: TNFo induces IL- 6 production by astrocytes but not microglia. Brain Res 1992;583:296-299.

38 Sawada M, Suzumura A, Marunouchi T: Cytokine network in the central nervous system and its roles in the growth and differentiation of glial and neuronal cells. Int $\mathbf{J}$ Dev Neurosci 1995;13:253-264. 